\title{
The Influence of Value-Creation on Customer's Based Destination Brand Equity: Case Study Daerah Istimewa Yogyakarta and Magelang in Indonesia
}

\author{
Gracia Naomi Hanaka ${ }^{1}$, Agung Nugroho ${ }^{1 *}$ \\ ${ }^{1}$ Faculty of Economics and Business, Universitas Indonesia \\ Email: a.nugroho@ui.ac.id
}

\begin{abstract}
Indonesian Government has shown an incredible effort to increase tourism sector's productivity by investing on infrastructures. However, to achieve this goal, branding effort needs to be employed because branding added value to its product. Measuring how the destination brand adds value to its product can be captured by Customers-Based Destination Brand Equity (CBDBE). It is important to recognize its dimensions to increase CBDBE and develop competitive strategy through Value- Creation Experience in Tourist Destination (VCETD). VCETD assesses the value-creation for tourists during their entire experience of a destination (before, during, and after their stay). Thus, this research aimed to answer two questions. First, to confirm the dimensions of CBDBE and VCETD. Second, to find out the antecedence influence of VCETD to CBDBE for planning competitive strategy. This concept was tested on Daerah Istimewa Yogyakarta and Magelang where the data collection was conducted in Departure Terminal in AdiSutjipto Airport and Borobudur temple with direct questionnaire. Then, it was analyzed using Structural Equation Modelling (SEM), whereas confirming the dimensions of VCETD and CBDBE using Second Order Confirmatory Factor Analysis then followed by Structural Model to assess the antecedence influence between the two. The results show that there are five dimensions of destination brand equity, which are destination brand awareness, destination brand image, destination brand quality, destination brand value, and destination brand loyalty and three dimensions of value creation, which are value-creation pre visit, value-creation during visit, value-creation post visit. Moreover, value-creation is proven to be significant ( $\mathrm{t}$-value $=8.45$ ) as an antecedent by which the customer perceives greater Destination Brand Equity.
\end{abstract}

Type of paper: Empirical

Keywords: Service Marketing; Tourism; Customers-Based Destination Brand Equity; ValueCreation Experience in Tourist Destination; Destination Branding; Value-Creation; Daerah Istimewa Yogyakarta; Borobudur 


\section{Introduction}

Travel and tourism's impact on the economic and social development of a country can be enormous; open new opportunities for business, trade and capital investment, creating jobs and entrepreneurialism for the workforce and protecting heritage and cultural values (Turner, 2015). In Indonesia case, Coordinating Minister of Maritime and Resources, Rizal Ramli, said that tourism is the sector with the most potential to bring foreign exchange and is the easiest way to create jobs with lower investment per person compared to capital-intensive industry (Ministry of Tourism Republic of Indonesia, 2015).

Besides being the source of foreign exchange, it is mentioned that employment's effects in tourism provides significant role for poverty reduction strategy (Harrison \& Schipani, 2007). Moreover, Spillane (1987) argues that tourism could be the right solution to overcome unemployment due its nature as labor intensive industry, which is suitable with Indonesia's condition as third world country with abundance supply of low-wage workers.

Due to those significant roles of tourism contributing to national economy, Coordinating Minister of Tourism and Creative Economy of Republic Indonesia, Arief Yahya, targeted that for Indonesia's tourism in 2019, Indonesia will have 20 million tourists from all over the world (Ministry of Tourism Republic of Indonesia, 2015). The administration of President Joko Widodo shows the seriousness in encouraging tourism as one of the economic drivers (Jefriando, 2016). Bali's success as world class tourist destination inspired President Joko Widodo to exploit other tourist destinations beyond Bali, which is known as "Ten of Bali" Program (Prodjo, 2016). These 10 priority strategic tourism destinations include, Morotai in Maluku, Labuan Bajo in West Nusa Tenggara, Tanjung Lesung in Banten, Tanjung Kelayang in Belitung, Wakatobi in Southeast Sulawesi, Lake Toba in North Sumatra, Bromo-TenggerSemeru in East Java, the Thousand Islands in Jakarta, Mandalika in West Nusa Tenggara, and Borobudur in Magelang Central Java

In the context of tourism industry, Destination Management Organizations (DMOs)' major purpose is to market their destination to potential visitors, both individuals and groups to provide economic benefit to the community and its members (Blain et al., 2005). To attract more potential visitors into the destination, DMOs play an important role in sustained destination competitiveness by cultivating resources that could create competitive advantage, which is by brand-building of the destination (Jamilena et al., 2016). Ferns \& Walls (2012) stated that DMOs can improve their marketing productivity by understanding the destination brand perceived by the consumers, known as brand on customer-based view. Since concern about adding value of brand to the product, those adding values could be captured by "equity" (Gartner et al., 2011). In tourism context, the branding literature offers performance instrument to evaluate and measure customer perceptions of destination brand is through Customer-Based Destination Brand Equity (Ferns \& Walls, 2012). However, there is a lack of agreement on the effective dimensions to measure brand equity (Jamilena et al., 2016). Majority agreed the measurement of customer-based brand equity is classified into four dimensions: awareness, image, perceived quality, and loyalty (Konecnik \& Gartner, 2007; Ferns \& Walls, 2012). Yet, other dimensions are added into measurement, such as brand associations (Im et al., 2012) and brand assets (Kladou \& Kehagias, 2013). Therefore, this study attempts to confirm suggested dimensions by Jamilena et al. (2016) as a significant measurement of customer-based destination brand equity and the application of the dimensions in case study. In this study, customer-based 
destination brand equity is measured by five dimensions suggested, which are destination brand awareness, destination brand Image, destination brand quality, destination brand value, and destination brand loyalty.

In this study, the researchers examined the theory to solve the branding issue using case study Daerah Istimewa Yogyakarta (DIY) and Magelang. There are three rationale behind the researchers' decision of choosing DIY and Magelang. First, the number of foreign tourist in DIY is still dominating compared to other ten strategic destinations chosen by President Joko Widodo by 11,177 (Statistics Indonesia Bali Province, 2016). Second, DIY and Magelang has various tourist destinations, including exotic beaches and Borobudur, which is one of the world's seven wonders. Third, the ministry of public works and public housing have stated that it will focus on infrastructure development for three destinations in the next two years, namely Lake Toba, Mandalika and Borobudur (Susanty, 2016). Development for borobudur includes initiatives such as self-built housing development in Magelang, a toll road connecting Yogyakarta and Bawen, a regional drinking water system, and reconstruction and expansion of several roads (Susanty, 2016).

This paper is organized as follows. The second section provides theoretical background to the research context, followed by development of hypotheses and the model. The third section describes the research methodology, data collection and measures used in this study. The fourth section explores the findings of the study. The last section concludes the discussion with managerial and recommendation for future research.

\section{Literature Review}

\subsection{Customer's Based Destination Brand Equity}

Brand is an instrument that makes a difference between products (Keller, 1998). Since the purpose of branding strategies is adding value, what gives a brand value can be captured through equity (Gartner et al., 2011). Equity is the total of consumers' perceptions and feeling about the product attributes and how they perform, about the brand name and what it stands for, and about the company that is associated with the brand (Keller, 1998). Basically, the demand-side or output perspective on branding has mostly been introduced through the concept of customerbased brand equity (Gartner et al., 2011). Aaker (1991) defined customer-based brand equity as a collection of assets and liabilities in a brand, as in the symbol, logo, and the name used by the brand, which could add or subtract from the value provided by a product or service to customers.

Customer-based destination brand equity can be defined as the combination of key factors that can be described as the overall utility that tourists place in the destination brand when compared to its competitors (Ferns \& Walls, 2012; Boo et al., 2009). Brand equity concept means the sum of factors contributing by brand's value in consumer's mind (Konecnik \& Gartner, 2007). The concept of customer-based brand equity has been view as comprising several dimensions because essentially brand has dimensions. (Gartner et al., 2011). Thus, the dimensions to measure customer-based destination brand-equity purpose in this research, 
based on Jamilena et al. (2016) are classified into five dimensions: awareness, quality, image, loyalty, and value. Each of the dimensions are explained below.

Brand Awareness represents the strength of the brand's presence in the mind of the target audience, along a continuum (Aaker, 1991). In tourism context, destination brand awareness is considered a main component of a brand's effect and consumers' purchasing decision (Boo et al., 2009). Destination brand awareness also perform a significant role in tourism decision process for travelers for destination choice as stated by Chon (1992) in Jamilena et al. (2016). In conclusion, destination brand awareness is dimensions of customer-based destination brand equity because being aware about the destination has significant contribution as the first step in tourist decision making process.

H1a: Destination Brand Awareness is significant dimension of Customer-Based Destination Brand Equity.

Destination Brand Quality refers to the consumer's perception of the overall quality of the facilities and nonphysical aspect of the destination or superiority of a product or service relative to relevant alternative and with respect to its intended purpose by Pike \& Bianchi (2013) (Jamilena et al., 2016). While, the quality is often viewed as simply meeting or exceeding expectations (Gartner et al., 2011). As its applied to product, if the destination considers having quality dimension, it will influence positively the purchase or repurchase decision (Konecnik \& Gartner, 2007). It is because the tourist's overall evaluation of a destination is a combination of products, services, and experiences makes quality is a vital element affecting consumer behavior.

H1b: Destination Brand Quality is significant dimension of Customer-Based Destination Brand Equity.

Brand Image is defined as the reasoned or emotional perceptions customers attach to specific brands (Keller, 1993). These beliefs, ideas, and impression could be the distinct set of associations linked to the brand that the consumer holds in memory (Ferns \& Walls, 2012). To achieve competitive advantage, the destination must first achieve tourist awareness and second a positive image (Konecnik \& Gartner, 2007). Images are used to create awareness and reduce risk to consumer associated with visiting a place one knows very little about. Hence, Destination Brand Image is important dimension to Customer-Based Destination Brand Equity because when consumers hold some favorable strong and unique brand association of an attribute in memory, it plays significant role for evaluation and selection process (Konecnik \& Gartner, 2007).

H1c: Destination Brand Image is significant dimension of Customer-Based Destination Brand Equity.

Destination Brand Loyalty is measured by attitudinal loyalty. It can be described as the dispositional commitment or attitude a consumers-travelers has toward a destination, measured by intent to visit and positive word-of-mouth (Pike \& Bianchi, 2013). In tourism context, Destination brand loyalty is essential for achieving repeat visitation and positive word of mouth among visitors and it is become the dependent variable in modeling Customer-Based Brand Equity (Konecnik \& Gartner, 2007; Gartner et al., 2011; Pike \& Bianchi, 2013). 
H1d: Destination Brand Loyalty is significant dimension of Customer-Based Destination Brand Equity.

Destination brand value suggested is an overall evaluation of a service's utility, based on customers' perceptions of what is received at what price (Zeithaml \& Bitner, 2000 in Pike \& Bianchi, 2013). Lassar et al. (1995) noted that customer choice of a brand depends on a perceived balance between the price of a product and its utility (Boo et al., 2009).

H1e: Destination Brand Value is significant dimension of Customer-Based Destination Brand Equity.

\subsection{Value-Creation Experience of Tourist Destination}

Value-Creation means not only focusing on how customers can be engaged in co- creating with the supplier, but also suppliers should also focus on developing more of a direct presence in their customers' lives (Jamilena et al., 2016). This service-centered perspective on valuecreation emphasizes interaction between customer and supplier as central to value-creation (Jamilena et al., 2016).

Worth highlight, the dynamic nature of value-creation, which alters over the course of the consumption experience (Grönroos \& Voima, 2013). Therefore, Value-creation is generated throughout the entire consumption experience (Jamilena et al., 2016). In the tourism context, it is useful to consider the three stages of the consumption process for a tourism stay: the pre-visit stage, the during-visit stage, and the post-visit stage (Jamilena et al., 2016).

Based on the work of Grönroos (2011) in (Jamilena et al., 2016), in the functions in pre-visit stage, the tourist recognizes the need for the trip, accesses information from different ASTs, and plans their stay, including making the relevant bookings.

H2a: Value-creation in the pre-visit phase is significant dimension of Value-Creation Experience of Tourist Destination.

Based on the work of Grönroos (2011) in (Jamilena et al., 2016), in the functions in during visit stage for customers, are consumption of the experience at the destination and the services and offers selected. Identification of new needs once at the destination, leading to a new process of information-search, decision-making, planning, booking, making service reservations, etc.

$\mathrm{H} 2 \mathrm{~b}$ : Value-creation during the visit phase is significant dimension Value-Creation Experience of Tourist Destination

Based on the work of Grönroos (2011) in (Jamilena et al., 2016), referring to the tourist's evaluation of the experience once they have consumed their stay. In the functions in post visit stage are the evaluation of the tourist stay, intention to share resources and experience with other participants from the destination and other members of the personal ecosystem (Jamilena et al., 2016). 


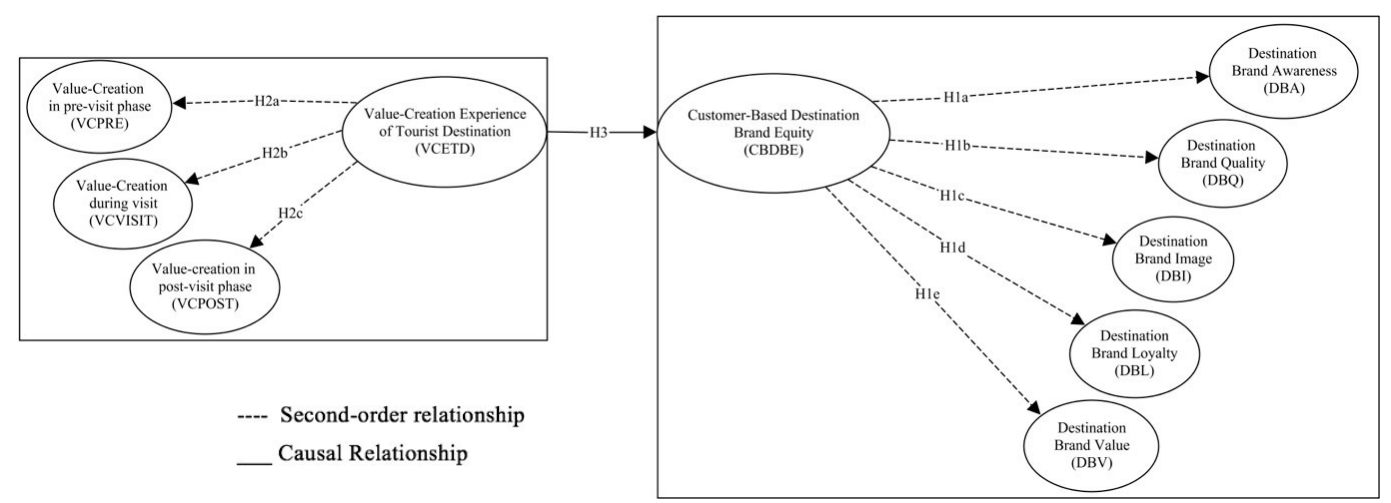

Figure 1. Conceptual Research Model

H2c: Value-creation during the post-visit phase is significant dimension Value-Creation Experience of Tourist Destination

As value-creation means suppliers focusing on more of a direct presence in their customers' lives by emphasizing the interaction between customer and supplier (Jamilena et al., 2016). It means the activities of ASTs able to generates greater value during travelers' consumption experience (Jamilena et al., 2016). Aaker (1996) stated that any interaction with the brand component will influence the customers' evaluation regarding the brand. Thus, the customer's value-creation plays an important role in brand- formation (Brodie et al., 2016) and therefore is likely to influence evaluations of Customer-Based Destination Brand Equity (Merz et al., 2009).

H3: Value-creation Experience of Tourist Destination has positive influence on CustomerBased Destination Brand Equity.

\section{Research Methodology}

This research aimed to discover the correlation among the variables at one period of time. Hence, the correct research approach for this study is conclusive research design with descriptive crosssectional study. This research used primary data, which was obtained through questionnaire. The questionnaire was distributed directly to the respondents according to sampling method.

\subsection{Measurement of Constructs}

The constructs identified based on theoretical background are Customer's-Based Destination Brand Equity (CBDBE) and Value-Creation Experience in Tourist Destination (VCETD). It should be transformed into measurement variable and subject to testing by operationalized it according to the underlying theory discussed above. This measurement item is using interval scale of 7 Points Likert Scale.

\subsection{Questionnaire Design}

The questionnaire is divided into three parts, which are screening questions, main part, and respondent profile. The question structure in the questionnaire used both structured and unstructured questions. Where, the structure question used 7 points Likert Scale and multiple choice question. While, the unstructured question is using open-ended question. The reason for the researcher to add unstructured questions is to assist the researcher interpret and 
analyze further respondents' responses to structured questions. Moreover, this research was using two types of questionnaires, which is English and Indonesian questionnaire, to accommodate domestic and international tourist.

\subsection{Sampling Design}

Population of this study is tourist both domestics and foreigners, who had completed their travel/ stay recently or in the end of their period of stay at Daerah Istimewa Yogyakarta and Magelang as tourist destination. The research used sample to make inferences about the population parameters, hence the sample should satisfy the sample criteria according population. the sample criteria are a tourist, which is match with the criteria that define tourist according to Robert C. Mill. The criteria are not currently working, a student, and domicile in the tourist destination area. While, the purpose and motivation to travel is liberal (Mill, 1990). Moreover, the respondent is a tourist who had completed their travel/stay recently or in the end of their period of stay in specified tourist destination area. The researcher included those criteria in screening questions.

Sampling Method used is non-probability sampling and the technique used is the quota sampling. In this research, the relevant control characteristic is the proportion of international tourist and domestic tourist to ensure the composition of the sample is the same as the composition of the population (Malhotra, 2010). The proportion of the population composition domestic tourist and international tourist 3,813,720 (93\%) and 308,485 (7\%) respectively (Tourism Agency of Daerah Istimewa Yogyakarta, 2015). Therefore, the sample composition refers to the population proportion. The minimum sample size for main test is 185 respondents, five times 37 measurement items.

\subsection{Data Collection and Analysis}

Pre-test questionnaire distribution was conducted between March 1st, 2017 and March 15th 2017 in Jabodetabek area using convenience sampling. Due to the different sample characteristic with the intended population, the researcher had made sure that the respondents had personally organized and undertaken a trip to a tourist destination in the previous six months. 30 respondents were collected with composition of 15 respondents using Questionnaire English and 15 respondents using Questionnaire in Indonesian. Data extracted from pre-test processed by software IBM SPSS Statistics 21, whether the measurement item has satisfied validity (KMO and Factor Loading > 0.5) and reliability (Cronbach's Alpha > 0.6) cut off.

Main data collection through questionnaire was conducted between April 7th, 2017 to April 20th, 2017. The researcher distribute questionnaire face-to-face in Daerah Istimewa Yogyakarta, to be specific International and National Departing Terminal of Adisucipto International Airport and the most popular tourist attraction in Magelang, Central Java is Borobudur temple. 266 respondents were obtained and 256 case included in the data analysis. The number of sample element size according to percentage of population composition, due to using quota sampling, is 238 cases $(93 \%)$ for domestic tourist, while 18 cases $(7 \%)$ for international tourist. The 256 cases were analyze using two step approach of Structural Equation Modeling, which are Confirmatory Factor Analysis and structural model. The measurement model in this research is conducted for the first-order and second-order CFA to analyze Hypothesis 1 and 2. While, continue with structural model to assess the third hypothesis. 
Table 1. Respondents' Profile

\begin{tabular}{|c|c|c|c|}
\hline Variable & $\%$ & Variable & $\%$ \\
\hline Gender & & Motivation to Visit & \\
\hline Female & $54.3 \%$ & Climate/ atmosphere/ environment & $13.7 \%$ \\
\hline Male & $45.7 \%$ & Relaxation/ having a good time & $47.3 \%$ \\
\hline Age & & Adventure/ something new/ curiosity & $23.0 \%$ \\
\hline $15-24$ & $30.5 \%$ & Personal reason, include prestige & $3.1 \%$ \\
\hline $25-34$ & $32.4 \%$ & Educational: cultures, how other live, etc. & $12.9 \%$ \\
\hline $35-44$ & $21.5 \%$ & Long Stay & \\
\hline $45-54$ & $12.9 \%$ & Less or equal to 3 days & $39.8 \%$ \\
\hline $55-64$ & $2.7 \%$ & 4-6 days & $52.0 \%$ \\
\hline $64<$ & 0 & $7-14$ days & $6.6 \%$ \\
\hline Nationality & & above 14 days & $1.6 \%$ \\
\hline Indonesian & $93 \%$ & Visit Frequency & \\
\hline Others: Dutch & \multirow{6}{*}{$7 \%$} & 1 times & $27.7 \%$ \\
\hline Chinese & & $2-5$ times & $53.1 \%$ \\
\hline Canadian & & above 5 times & $19.1 \%$ \\
\hline Japanese & & Information Source & \\
\hline Korean & & $\mathrm{TV}$ & $19.1 \%$ \\
\hline Australian & & Internet & $79.7 \%$ \\
\hline Purpose to Travel & & Travel Agents & $10.5 \%$ \\
\hline Vacation & $80.5 \%$ & Newspaper and Magazine & $6.6 \%$ \\
\hline Business & $5.9 \%$ & Others: School & $19.5 \%$ \\
\hline Convention / exhibition & $.4 \%$ & Friends and Family & \\
\hline Vacation and business & $7.8 \%$ & Driver & \\
\hline Visiting friends/ relatives & $5.5 \%$ & Brochure & \\
\hline
\end{tabular}

Table 2. Latent Variables Validity and Reliability 1st Order CFA

\begin{tabular}{|l|l|l|l|l|l|}
\hline Latent and Observed Variables & SLF & T-Value & CR & VE \\
\hline Destination Brand Awareness (DBA) & 0.77 & 13.91 & 0.86 & 0.61 \\
\hline DBA1 & 0.81 & 14.92 & & \\
\hline DBA2 & 0.82 & 15.24 & & \\
\hline DBA3 & 0.72 & 12.59 & & \\
\hline DBA4 & 0.80 & 14.83 & 0.89 & 0.67 \\
\hline Destination Brand Quality (DBQ) & \multicolumn{5}{|l|}{} \\
\hline DBQ1 & 0.85 & 16.26 & & \\
\hline DBQ2 & 0.81 & 15.24 & & \\
\hline DBQ3 & 0.72 & 12.83 & & \\
\hline DBQ4 & 0.68 & 11.77 & 0.84 & 0.51 \\
\hline Destination Brand Image (DBI) & 0.75 & 13.46 & & \\
\hline DBI1 & 0.72 & 12.77 & & \\
\hline DB12 & 0.68 & 11.77 & & \\
\hline DB13 & 0.74 & 13.27 & & \\
\hline DBI4 & 0.84 & 15.96 & 0.86 & 0.61 \\
\hline DBI5 & 0.83 & 15.60 & & \\
\hline Destination Brand Loyalty (DBL) & 0.69 & 11.95 & & \\
\hline DBL1 & 0.76 & 13.72 & & \\
\hline DBL2 & & & \\
\hline DBL3 & & \\
\hline DBL4 & \multicolumn{5}{|l|}{} \\
\hline
\end{tabular}

\begin{tabular}{|c|c|c|c|c|}
\hline Latent and Observed Variables & SLF & T-Value & CR & VE \\
\hline \multicolumn{5}{|l|}{ Destination Brand Value (DBV) } \\
\hline DBV1 & 0.80 & 15.29 & 0.93 & 0.73 \\
\hline DBV2 & 0.81 & 15.41 & & \\
\hline DBV3 & 0.86 & 17.07 & & \\
\hline DBV4 & 0.90 & 18.23 & & \\
\hline DBV5 & 0.91 & 18.75 & & \\
\hline \multicolumn{5}{|l|}{ Value-Creation Pre-Visit (VCPRE) } \\
\hline VCPRE1 & 0.60 & 9.73 & 0.77 & 0.46 \\
\hline VCPRE2 & 0.72 & 12.07 & & \\
\hline VCPRE3 & 0.73 & 12.28 & & \\
\hline VCPRE4 & 0.67 & 11.02 & & \\
\hline \multicolumn{5}{|c|}{ Value-Creation During Visit (VCVISIT) } \\
\hline VCVISIT1 & 0.56 & 9.25 & 0.82 & 0.48 \\
\hline VCVISIT2 & 0.67 & 11.57 & & \\
\hline VCVISIT3 & 0.65 & 11.11 & & \\
\hline VCVISIT4 & 0.81 & 14.92 & & \\
\hline VCVISIT5 & 0.76 & 13.56 & & \\
\hline \multicolumn{5}{|c|}{ Value-Creation Post Visit (VCPOST) } \\
\hline VCPOST1 & 0.75 & 13.40 & 0.89 & 0.62 \\
\hline VCPOST2 & 0.75 & 13.56 & & \\
\hline VCPOST3 & 0.74 & 13.18 & & \\
\hline VCPOST4 & 0.73 & 12.92 & & \\
\hline VCPOST5 & 0.79 & 14.44 & & \\
\hline
\end{tabular}


Table 3. CBCBE Dimensions Validity

\begin{tabular}{|l|l|l|l|l|l|l|}
\hline \multicolumn{1}{|c|}{$\begin{array}{c}\text { Second } \\
\text { Order }\end{array}$} & \multicolumn{1}{|c|}{$\begin{array}{c}\text { First Order Variable } \\
\text { (Dimensions) }\end{array}$} & SLF & T-Value & $\mathbf{R}^{\mathbf{2}}$ & CR & VE \\
\hline \multirow{2}{*}{$\begin{array}{l}\text { Customers- } \\
\text { Based } \\
\text { Destination } \\
\text { Brand Equity }\end{array}$} & $\begin{array}{l}\text { Destination Brand } \\
\text { Awareness }\end{array}$ & 0.82 & 11.46 & 0.68 & & \\
\cline { 2 - 6 } & Destination Brand Quality & 0.87 & 12.56 & 0.76 & \multirow{2}{*}{0.91} & \multirow{2}{*}{0.67} \\
\cline { 2 - 6 } & Destination Brand Image & 0.89 & 10.54 & 0.78 & & \\
\cline { 2 - 6 } & Destination Brand Loyalty & 0.82 & 12.55 & 0.68 & & \\
\cline { 2 - 6 } & Destination Brand Value & 0.69 & 10.13 & 0.5 & & \\
\hline
\end{tabular}

Table 4. VCETD Dimensions Validity

\begin{tabular}{|l|l|l|l|l|l|l|}
\hline \multicolumn{1}{|c|}{$\begin{array}{c}\text { Second } \\
\text { Order }\end{array}$} & \multicolumn{1}{|c|}{$\begin{array}{c}\text { First Order Variable } \\
\text { (Dimensions) }\end{array}$} & SLF & T-Value & $\mathbf{R}^{\mathbf{2}}$ & CR & VE \\
\hline $\begin{array}{l}\text { Value- } \\
\text { Creation } \\
\text { Experience of } \\
\text { Tourist } \\
\text { Destination }\end{array}$ & Value Creation in Pre- Visit & 0.82 & 8.30 & 0.67 & & \\
\cline { 2 - 6 } & $\begin{array}{l}\text { Value Creation in During } \\
\text { Visit }\end{array}$ & 0.91 & 8.47 & 0.83 & 0.90 & 0.74 \\
\cline { 2 - 5 } & $\begin{array}{l}\text { Value Creation in Post } \\
\text { Visit }\end{array}$ & 0.85 & 10.75 & 0.72 & & \\
\hline
\end{tabular}

\section{4. $\quad$ Result}

The profile of the respondent shown in the Table 1.

\subsection{First Order Confirmatory Factor Analysis}

In First Order CFA, the result must satisfy three statistical cut off criteria, which are validity (SFL $>0.5$ and T-value $>1.96$ ), reliability (VE $\geq 0.5$ and $\mathrm{CR} \geq 0.7$ ), and Goodness of Fit (Hair et al., 2014; Wijanto, 2015). The result of First Order CFA shows in the Table 2.

Based on Table 2, it indicates that every latent variable has satisfied validity and reliability. The standardized loading factors of all observed variables is above 0.5 and T- value is above 0.7 . The construct reliability (CR) and variance extracted (VE) for all latent variable is above 0.7 and 0.5 respectively, except for VE of VCPRE and VCVISIT latent variable. However, Fornell (1981) in Huang et al. (2013), argues that the value of VE is still acceptable given the CR value is more than 0.6. Thus, it can be concluded that every latent variable is reliable. According to Hair et al. (2014), if three or four GOF measurements are a good fit, it indicates that the goodness of fit model is sufficient. There are more than four statistical value goodness of fit has good fit $(\mathrm{RMSEA}=0.065, \mathrm{SRMR}=0.052, \mathrm{ECVI}$, Normed Chi Square $=2.1017$, AIC, CAIC $)$.

\subsection{Second Order Confirmatory Factor Analysis}

The researchers intended to assess higher level measurement model using Second Order Confirmatory Factor Analysis, which aim to conclude hypothesis 1 and 2. This assessment 
is needed to confirm the dimensions of the second order variables, which in this research is Customers-based Destination Brand Equity (CBDBE) and Value-Creation Experience Tourist in the Destination (VCETD). Table 3 shows the result of Second Order CFA of CBDBE.

Moreover, it showed that overall fit of the model is sufficient. There are more than four statistical value Goodness of Fit has good fit (SRMR $=0.060$, ECVI, IFI $=0.90$, CFI $=0.90$, Normed Chi Square $=3.0017$, AIC, and CAIC). The result based on Table 3 all component is above statistical cut off and overall fit of the model indicate that CBDBE is latent variable that have five dimensions: Destination Brand Awareness, Destination Brand Quality, Destination Brand Image, Destination Brand Loyalty, and Destination Brand Value and can be measured through its dimensions.

The result of Second Order CFA of VCETD to validate the measurement is shown of Table 4.

In addition, it showed that overall fit of the model is sufficient. There are more than four statistical value Goodness of Fit has good fit $(\mathrm{GFI}=0.93, \mathrm{SRMR}=0.045, \mathrm{RMSEA}=0.053, \mathrm{ECVI}, \mathrm{NNFI}$ $=0.95, \mathrm{NFI}=0.92, \mathrm{AGFI}=0.91, \mathrm{RFI}=0.90, \mathrm{IFI}=0.96, \mathrm{CFI}=0.96$, Normed Chi Square $=$ 1.7292, AIC, and CAIC). As depicted on Table 4, all component is above statistical cut off and overall fit of the model indicate that VCETD is latent variable that have five dimensions: Value Creation in Pre-Visit, Value Creation in During Visit, and Value-Creation in Post Visit and can be measured through those dimensions.

\subsection{Structural Analysis}

The model proposed in this research is, which is the third hypothesis is Value- Creation Experience Tourist in the Destination (VCETD) influence Customers-based Destination Brand Equity (CBDBE). The result shown that showed that overall fit of the model for the structural model is sufficient. There are more than four statistical value Goodness of Fit has good fit $(\mathrm{SRMR}=0.056, \mathrm{RMSEA}=0.064, \mathrm{ECVI}$, Normed Chi Square $=2.0447$, AIC, and CAIC $)$. Moreover, in Figure 2. the indicator cut off to assess the causa relationships has satisfied $(\mathrm{T}$-value $=8.45$ and SLF $=0.75)$, which is above 1.645 and 0.05 respectively. In addition, Coefficient Determination (R2) of the regression equation is 0.56 , which is preferable because indicates that the variance of dependent variable explained by independent variable is higher than the error.

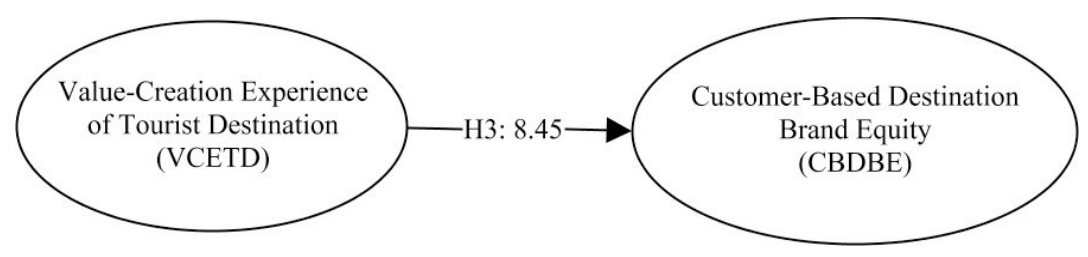

Figure 2. Path Diagram and T-Value Results 
Table 5. Summary of Hypothesis Testing Result

\begin{tabular}{|c|c|c|c|}
\hline Hypothesis & Path & $\begin{array}{c}\text { T-Value } \\
\text { (SLF) }\end{array}$ & Conclusion \\
\hline $1 \mathrm{a}$ & $\begin{array}{l}\text { Destination Brand Awareness is } \\
\text { significant dimension of Customer- } \\
\text { Based Destination Brand Equity. }\end{array}$ & $\begin{array}{l}11.46 \\
(0.82)\end{array}$ & $\begin{array}{l}\text { Data support } \\
\text { hypothesis }\end{array}$ \\
\hline $1 b$ & $\begin{array}{l}\text { Destination Brand Quality is } \\
\text { significant dimension of Customer- } \\
\text { Based Destination Brand Equity. }\end{array}$ & $\begin{array}{l}12.56 \\
(0.87)\end{array}$ & $\begin{array}{l}\text { Data support } \\
\text { hypothesis }\end{array}$ \\
\hline 1c & $\begin{array}{l}\text { Destination Brand Image is } \\
\text { significant dimension of Customer- } \\
\text { Based Destination Brand Equity. }\end{array}$ & $\begin{array}{l}10.54 \\
(0.89)\end{array}$ & $\begin{array}{l}\text { Data support } \\
\text { hypothesis }\end{array}$ \\
\hline 1d & $\begin{array}{l}\text { Destination Brand Loyalty is } \\
\text { significant dimension of Customer- } \\
\text { Based Destination Brand Equity. }\end{array}$ & $\begin{array}{l}12.55 \\
(0.82)\end{array}$ & $\begin{array}{l}\text { Data support } \\
\text { hypothesis }\end{array}$ \\
\hline $1 \mathrm{e}$ & $\begin{array}{l}\text { Destination Brand Value is } \\
\text { significant dimension of Customer- } \\
\text { Based Destination Brand Equity. }\end{array}$ & $\begin{array}{l}10.13 \\
(0.69)\end{array}$ & $\begin{array}{l}\text { Data support } \\
\text { hypothesis }\end{array}$ \\
\hline $2 \mathbf{a}$ & $\begin{array}{l}\text { Value-creation in the pre-visit phase } \\
\text { is significant dimension of Value- } \\
\text { Creation Experience of Tourist } \\
\text { Destination. }\end{array}$ & $\begin{array}{l}8.30 \\
(0.82)\end{array}$ & $\begin{array}{l}\text { Data support } \\
\text { hypothesis }\end{array}$ \\
\hline $2 b$ & $\begin{array}{l}\text { Value-creation during the visit phase } \\
\text { is significant dimension Value- } \\
\text { Creation Experience of Tourist } \\
\text { Destination }\end{array}$ & $\begin{array}{l}8.47 \\
(0.91)\end{array}$ & $\begin{array}{l}\text { Data support } \\
\text { hypothesis }\end{array}$ \\
\hline $2 c$ & $\begin{array}{l}\text { Value-creation during the post-visit } \\
\text { phase } \mathrm{i} \mathrm{s} \text { significant dimension } \\
\text { Value-Creation Experience of } \\
\text { Tourist Destination }\end{array}$ & $\begin{array}{l}10.75 \\
(0.85)\end{array}$ & $\begin{array}{l}\text { Data support } \\
\text { hypothesis }\end{array}$ \\
\hline 3 & $\begin{array}{l}\text { Value-creation Experience of Tourist } \\
\text { Destination has positive influence on } \\
\text { Customer-Based Destination Brand } \\
\text { Equity. }\end{array}$ & 8.45 & $\begin{array}{l}\text { Data support } \\
\text { hypothesis }\end{array}$ \\
\hline
\end{tabular}




\section{Discussion and Conclusion}

In this research, there are three main hypotheses. Table 5 represents the summary of hypothesis testing in the research model.

The first objective is confirming the five dimensions of Customers-Based destination brand equity, which are destination brand awareness, destination brand image, destination brand quality, destination brand value, and destination brand loyalty. This objective is represented in the first hypothesis, H1a- H1e, based on the outcome confirming the five dimensions of Customers-Based Destination Brand Equity through second- order CFA. It can be concluded in the statement below:

- Destination Brand Awareness is a Based Destination Brand Equity. Since achieving greater level of Brand Equity equal to achieving the destination's competitive advantage, the outcome indicates to increase Daerah Istimewa Yogyakarta and Magelang's Brand Equity, the marketers can do so by increasing the customers' evaluation towards the awareness of the destination brand.

- Destination Brand Quality is a significant dimension of Customers-Based Destination Brand Equity. The outcome indicates that as the marketers increase the customers' evaluation on Destination Brand Quality, the destination competitive advantage will improve as the level of Destination Brand Equity improve.

- Destination Brand Image is a significant dimension of Customers-Based Destination Brand Equity. The outcome indicates if visitors of Daerah Istimewa Yogyakarta and Magelang have positive Destination Brand Image, it will become an asset of Destination Brand Equity because image is an important source of competitive advantage. In fact, Destination Brand Image is the most contributing dimensions of Brand Equity because it has the highest SLF. Thus, the marketers could increase destination competitive advantage by developing more positive image of the destination.

- Destination Brand Loyalty is a significant dimension of Customers-Based Destination Brand Equity. The result shows that if the customers consider themselves to have high attitudinal loyalty, because they have positive word-of mouth (recommendation to others) and revisit intention, it will be the brand asset of Daerah Istimewa Yogyakarta and Magelang. If the marketers can increase attitudinal loyalty of the customers, they will increase the Brand Equity level, which also contributes to destination competitive advantage.

- Destination Brand Value is a significant dimension of Customers-Based Destination Brand Equity. When the tourists consider the offering in Daerah Istimewa Yogyakarta and Magelang is valuable, it will increase the competitive advantage of the destination.

The second objective is confirming the dimension of Value-Creation for Tourist's Experience in a Destination, which are value-creation in the pre-visit stage, value-creation during the visit, and value-creation during post visit. This objective is represented in the second hypothesis, $\mathrm{H} 2 \mathrm{a}-\mathrm{H} 2 \mathrm{c}$. This is based on the result confirmation of three dimension 
of Value-Creation for Tourist's Experience in a Destination through second-order CFA. It can be concluded in the statement below:

i. Value-Creation in the Pre-Visit is a significant dimension of Value-Creation for Tourist's Experience in a Destination. This means that to determine the meaningful interaction between ASTs that creates value to tourists and other tourist in overall tourist experience, thus the marketers could capture it through the interaction between ASTs that create value to tourists in Pre-Visit phase. It is worth to be noted that tourists could make interaction with ASTs (Agencies Suppliers Tourist) directly (face-to-face) or indirectly (through websites, blogs, or social media) must include the consideration. Moreover, the interaction must be positive, hence the tourists perceived it as valuecreation for them.

ii. Value-Creation During the Visit is a significant dimension of Value-Creation for Tourist's Experience in a Destination. This means that determining the meaningful interaction between ASTs that creates value to tourists and other tourist in overall tourist experience, the marketers then could capture it through during visit phase, such as fulfilling needs at the destination and consuming of the experience of services selected. In fact, Value- Creation During visit is the most contributing dimensions of Value-Creation because it has the highest SLF.

Iii Value-creation in the Post Visit is a significant dimension of Value-Creation for Tourist's Experience in a Destination. This is to measure Value-Creation the researcher could gauge in interaction between ASTs and tourist in the post visit phase. This valuable interaction in the post visit phase is to present the evaluation of their stay and intension to share their experience with ASTs.

The third objective is capturing the antecedence influence of Value-Creation for Tourist's Experience in a Destination on Customer-Based Destination Brand Equity. Based on the outcome, it could be concluded that there is influence effect from Value-Creation Experience in Tourist Destination on Customer-Based Destination Brand Equity. It implies that for Destination Management Organizer to increase consumers brand evaluation, they could accomplish it by increasing the value-creation for tourist's experience in the destination. The logic behind it is when the brand add value to the product, it increases competitive advantage. The value created is in form of positive interaction between ASTs and tourists in three different phases. Therefore, by increasing DBE level the management could build and imply strategy focusing on developing value for tourists.

\section{Implication}

Based on the research findings, there are several things need to be highlighted owing to the fact that it is important for several parties: the Destination Management Organizers, which are DMOs in national level (Ministry of Tourism Republic of Indonesia); province Level (Tourism Agency Daerah Istimewa Yogyakarta and Central Java), and tourist attraction level (PT Taman Wisata Candi Borobudur, Prambanan, dan Ratu Boko);the service suppliers, which include accommodation, transportation, and travel organizers. Service suppliers recognize as business parties. 
The following is the strategy suggested to respond three main outcomes above. The strategy organized according to development of Value-Creation by each phases of pre-visit, during visit, and post visit, which organized by government and business parties for domestic andinternational tourists. This strategy will impact the Brand Equity, which reflected through its dimensions.

1. Strategy to increase Value Creation in overall tourist experience is by increasing the positive interaction between government and business parties with the tourist.

The researchers recommend DMOs to re-organize the organization and develop integration between DMOs level. DMOs and service suppliers must have the same vision of the destination and increase their coordination, so it will be beneficial to both parties.

2. Strategy to increase the Value Creation for tourists in Pre-Visit Phase and the impact Towards Dimensions of Destination Brand Equity Daerah Istimewa Yogyakarta and Magelang.

There are several actions suggested by researchers to increase Destination Brand Awareness and Image in Pre-Visit phase in form of promotional strategy. It begins with the advertisement content that convey source of differentiation of Daerah Istimewa Yogyakarta and Magelang and international with domestic tourists' advertising should be different. Second, promotions through film, drama, and TV shows. Furthermore, the DMOs and service suppliers could lower customers' searching cost to make value to increase Destination Brand Quality and Destination Brand Value by these actions.

i. For international tourists, it is better to sell the full tourism package services to the foreign country's local tour agents. The itinerary should be designed by DMOs (National and Local government) and discussed it with their local tour agents.

ii. Each of services suppliers (e.g. accommodations, transportation) could coordinate with travel agents to provide high quality experience with the valuable price by trading quantity discount.

iii. For domestic tourists, the online platform for booking integrated tourism product from transportation (flights and train) to accommodation should able to book for tourist attractions as well and make the bundling price for semi-full package tourism, including the airplane, hotel, and several tourist attraction's entrance ticket.

3. Strategy to Increase the Value Creation for tourists in During Visit Phase and the Impact Towards Dimensions of Destination Brand Equity Daerah Istimewa Yogyakarta and Magelang.

There are several strategies for government and service supplier to increase value- creation in during visit phase.

i. DMO (Local Government) could control tourist attraction quality by including them in their possession.

ii. Ensure that every tourist attraction offers have satisfied standard criteria is one of the actions, such as toilet and pray area in quantity and quality. 
iii. Increase special acts and events attract tourists who have been into the tourist attraction to enjoy new offering.

iv. Increase the materials given to tourist by providing MP3 players option with earphone filled with historic or background explanation about the tourist attractions that consist of large selection languages in the world.

v. Manage the unregulated cadger or street vendors.

vi. Integrated the transportation and ensure that the price is standardized.

vii. Service suppliers should establish websites and applications dedicated to for transportation mode exist to travel to certain places, such as gothere.sg.

4. Strategy to Increase the Value Creation for tourists in Post Visit Phase and the Impact Towards Dimensions of Destination Brand Equity Daerah Istimewa Yogyakarta and Magelang.

There are several strategies for government and service supplier to increase value- creation in post visit phase.

i. assist service suppliers quickly from the feedback collection through service suppliers' DMOs could support financially well-known traveler blogger to report about the experience in Daerah Istimewa Yogyakarta and Magelang.

ii. Increase social media sharing of the experience is also could be accomplish by making promotion on tourism entrance tickets or tour guide.

iii. Respond and customer satisfaction and evaluation survey.

iv. Encourage tourist to give review by comments or ratings in tourism website, such as "tripadvisor", "agoda", and "traveloka" by giving promotional code for next booking purchase after posting reviews and ratings in respective tourism website.

v. Service suppliers could increase loyalty membership by making an account that count points that are related to their spending.

vi. Service suppliers should collect feedback from tourists when the service is completed, and report the feedback to province level DMOs, so that increase responsiveness by combining resources.

\section{Recommendation for Future Research}

i. Data collection should be conducted in larger area of Daerah Istimewa Yogyakarta and Magelang, as well as comparison between the high season and low season result.

ii. Adding subsequent variable of Destination Brand Equity, such as variable that could capture tourists' behavior and the result achievement of Destination Brand Equity, in terms of tourists' arrival or so on.

iii. The questionnaire should be simplified or data collected through personal interview, where there is plenty of time. Thus, the researcher could extract data from the respondent who did not familiar with Likert scale.

iv. It is recommended to conduct data collection using longitudinal research design, especially for sought information of value-creation. It will produce more accurate inferences to respond the tourists' short term memory regarding the evaluation of their experience in pre-visit, during visit, and post visit. 


\section{References}

Aaker, D. A. (1991). Managing Brand Equity. New York: Free Press.

Abdussalam, A. (2017, January 8). Govt to revoke visa-free facility. Retrieved May 10, 2017, from ANTARA News: http://www.antaranews.com/en/news/108827/govt-to-revokevisa-free-facility

Amindoni, A. (2016, February 3). Breakthroughs needed to accelerate tourism development: Jokowi. Retrieved October 2, 2016, from The Jakarta Post: http://www.thejakartapost.com/news/2016/02/03/breakthroughs-needed-acceleratetourism-development-jokowi.html

Boo, S., Busser, J., \& Baloglu, S. (2009). A model of customer-based brand equity and its application to multiple destinations. Tourism Management, 219-231.

Brodie, R. J., Glynn, M. S., \& Little, V. (2016). The service brand and the service-dominant logic: missing fundamental premise or the need for stronger theory? Marketing Theory, 363-379.

Budiman, A. (2016, January 30). Kembangkan Borobudur, Pemerintah Siapkan Rp 10 Triliun. Retrieved December 27, 2016, from Tempo.co: https://m.tempo.co/read/ news/2016/01/30/090740736/kembangkan-borobudur-pemerintah- siapkan-rp-10triliun

Ferns, B. H., \& Walls, A. (2012, September 15). Enduring travel involvement, destination brand equity, and travelers' visit intentions: A structural model analysis. Journal of Destination Marketing \& Management, 27-35.

García, J. A., Gómez, M., \& Molina, A. (2012). A destination-branding model: An empirical analysis based on stakeholders. Tourism Management, 646e661.

Gartner, W. C., Ruzzier, \& Konecnik, M. (2011). Tourism Destination Brand Equity Dimensions: Renewal versus Repeat Market. Journal of Travel Research, 471-481.

Global Business Guide Indonesia. (2012). Tourism: Untapping the Potential. Retrieved December 27, 2016, from Global Business Guide Indonesia: http://www.gbgindonesia.com/en/services/article/2011/tourism_untapping_the_poten tial.php

Grönroos, C., \& Voima, P. (2013). Critical service logic: making sense of value creation and co- creation. Academy of Marketing Science, 133-150.

Hair, J. F., Black, W. C., Babin, B. J., \& Anderson, R. E. (2014). Multivariate Data Analysis: 7th Edition. Harlow: Pearson Education Limited. 
Harrison, D., \& Schipani, S. (2007, June). Lao Tourism and Poverty Alleviation: CommunityBased Tourism and the Private Sector. Current Issues in Tourism, 194-230.

Ihsanuddin. (2016, December 1). Jokowi Ancam Copot Menteri Pariwisata. Retrieved February 16, 2017, from Kompas.com: http://nasional.kompas.com/read/2016/12/01/15565401/jokowi.ancam.copot.menteri .pariwisata

Im, H. H., Kim, S. S., Elliot, S., \& Han, H. (2012). Conceptualizing Destination Brand Equity Dimensions from a Consumer-Based Brand Equity Perspective. Journal of Travel \& Tourism Marketing, 385-403.

Jamilena, D. M., Peña, A. I., \& Molina, M. A. (2016). The Effect of Value-Creation on Consumer- Based Destination Brand Equity. Journal of Travel Research, 1-21.

Jefriando, M. (2016, February 2). Ini Rencana Besar Jokowi Kembangkan Danau Toba. Retrieved October 2, 2016, from Detik Finance: http://finance.detik.com/ekonomibisnis/3133245/ini- rencana-besar-jokowi-kembangkan-danau-toba

Keller, K. L. (1993, Jan). Conceptualizing, Measuring, and Managing Customer-Based Brand Equity. Journal of Marketing, 1-22.

Keller, K. L. (1998). Strategic Brand Management: Building, Measuring, and Managing Brand Equity. Upper Saddle River: Prentice Hall.

Kladou, S., \& Kehagias, J. (2013, November 27). Assessing destination brand equity: An integrated approach. Journal of Destination Marketing \& Management, 2-10.

Konecnik, M., \& Gartner, W. C. (2007). Customer-Based Brand Equity for a Destination. Annals of Tourism Research, 400-421.

Malhotra, N. K. (2010). Marketing Research: an applied orientation (6th Edition). Harlow: Prentice Hall.

Marbun, J. (2014, October 20). Berita Tokoh Indonesia. Retrieved October 2, 2016, from Jokowi expected to improve tourism infrastructure: http://www.tokohindonesia.com/ lintas- berita/artikel/492320/jokowi-expected-to-improve-tourism-infrastructure

Mill, R. C. (1990). Tourism: The Internasional Business. New Jersey: Prentice-Hall, Inc. Ministry of Tourism Republic of Indonesia. (2015, August 26). Pariwisata Kini Jadi Andalan

Pendulang Devisa Negara. Retrieved October 2, 2016, from Kementerian Pariwisata Republik Indonesia: http://www.kemenpar.go.id/asp/detil.asp? $c=16 \& i d=2959$ 
Morrison, A. M., \& Anderson, D. J. (2002). Destination branding. Annual Meeting of the Missouri association of convention and Visitor Bureaus (p. 17). Missouri, U.S.A: Missouri association of convention and Visitor Bureaus.

Muhammad, D., \& Ariyanto, Y. (2017, January 27). Jokowi Letakkan Batu Pertama Bandara Baru Yogyakarta. Retrieved April 17, 2017, from Liputan 6: http://news.liputan6.com/ read/2838834/jokowi-letakkan-batu-pertama-bandarabaru- yogyakarta

Pike, S., \& Bianchi, C. (2013). Destination Brand Equity for Australia: Testing a Model of CBBE in Short-Haul and Long-Haul Markets. Journal of Hospitality \& Tourism Research, 114-134.

Prodjo, W. A. (2016, Agustus 26). Ini Rencana Jokowi Kembangkan Danau Toba sebagai Destinasi Wisata Unggulan . Retrieved December 27, 2016, from Kompas Travel: http://travel.kompas.com/read/2016/08/26/180300427/ini.rencana.jokowi.kembangk an. danau. toba.sebagai.destinasi.wisata.unggulan

Purbaya Yudhi Sadewa, P., Nasution, D., \& Surendro, B. (2008). Early Economic Indicator. Jakarta: Danareksa Research Insititue.

Soegiarto, Y. (2015, April 19). From Aceh to Papua: Jokowi's Infrastructure Visions. Retrieved October 2, 2016, from Jakarta Globe: http://jakartaglobe.beritasatu.com/archive/aceh-papua-jokowis-infrastructure visions/

Spilllane, J. J. (1987). Ekonomi Pariwisata, Sejarah, dan Prospeknya. Yogyakarta: Kanisius.

Statistics Indonesia Bali Province. (2016). Perkembangan Pariwisata Bali Juli 2016. Bali: BPS Provinsi Bali.

Susanty, F. (2016, November 2). Big plans in store for Indonesia tourist destinations. Retrieved December 27, 2016, from The Jakarta Post: http://www.thejakartapost.com/news/2016/11/02/big-plans-in-store-for-indonesiatourist-destinations.html

Syatiri, A. S. (2016, September 26). Menarik Wisatawan ke Indonesia Terkendala Tak Ada "Direct Flight". Retrieved October 2, 2016, from Kompas Travel: http://travel.kompas.com/read/2016/09/29/070700227/menarik.wisatawan.ke.indone sia.terken dala.tak.ada. direct.flight

Tourism Agency of Daerah Istimewa Yogyakarta. (2015). Statistik Kepariwasataan 2015. Yogyakarta: Dinas Pariwisata Daerah Istimewa Yogyakarta.

Turner, R. (2015). Travel \& Tourism Economic Impact 2015 Indonesia. London: World Travel and Tourism Council. 
Widodo, W. S. (2016, March 31). 3 Masalah SDM Pariwisata Indonesia Bersaing di Tingkat Global. Retrieved October 2, 2016, from Detik Travel: http://ravel.detik.com/ $\mathrm{read} / 2016 / 03 / 31 / 080407 / 3176358 / 1382 / 3$-masalah-sdm-pariwisata-indonesiabersaing-di-tingkat-global

Wijanto, S. H. (2015). Metode Penelitian Menggunakan Structural Equation Modeling dengan LISREL 9. Jakarta: Lembaga Penerbit Fakultas Ekonomi Universitas Indonesia.

World Economic Forum. (2015). The Travel \& Tourism Competitiveness Report 2015. Geneva: World Economic Forum. 